\title{
Çocuk yoğun bakım hastalarında hiponatreminin klinik önemi
}

\author{
Fatih AYGÜN ${ }^{1}$, Seda ARAS ${ }^{2}$, Fatih VAROL ${ }^{1}$, Ahmet İRDEM $^{3}$
}

\begin{abstract}
$\ddot{\mathbf{O} z}$
Hiponatremi çocuk acil ve yoğun bakım ünitelerinde sık görülen bir elektrolit bozukluğudur. Yetişkin hastalarda hiponatreminin mortalite için bağımsız bir risk faktörü olduğu gösterilmesine karşın özellikle çocuk yoğun bakım (ÇYB) hastalarında hiponatreminin klinik önemi ve prognoza etkisi yeterince irdelenmemiştir. Bu çalışmada çocuk yoğun bakım ünitesi'nde (ÇYBÜ) yatırılan hastalarda ilk gün hiponatremi sıklığı ve erken dönem prognoz ile olan ilișkisinin araștırılması planlanmıștır. Ekim 2016 ile Mart 2018 tarihleri arasında yatırılan tüm hastaların verileri geriye dönük olarak incelenmiştir. Çalışmaya alınan 435 hastanın 22'sinde orta ve ağır düzeyde hiponatremi saptandı. Hastaların 12'si $(\% 54,5)$ erkek, 10 ’u $(\% 45,5)$ kızdı. Yaş dağılımları 1,5 ay ile 17 yaş arasında olup ortalama hasta yaşı $3,67 \pm 2,00$ yıldı. Hiponatremi saptanan hastaların ortalama yatış süresi $14,91 \pm 22,17$ gündü. Serum sodyum $(\mathrm{Na})$ düzeyinin düşüklüğ̈̈ $(\mathrm{Na}<130 \mathrm{mmol} / \mathrm{L})$ ile mekanik ventilatöre bağlanma, inotrop ilaç kullanımı, ÇYBÜ yatış süresi, çocuk mortalite (PRISM ) skoru, kan ürünü kullanımı, ölüm, akut böbrek hasarı ve kalp yetmezliği arasında istatistiksel anlamlı ilişki saptandı. Çocuk hastalarda ilk başvuru sırasında $\mathrm{Na}<130 \mathrm{mml} / \mathrm{L}$ olması mortalite ve morbidite ile ilişkili önemli bir prognostik belirteç olarak değerlendirilmelidir.
\end{abstract}

Yayın Bilgisi

Gönderi Tarihi:14.06.2018

Kabul Tarihi:29.07.2018

Online Yayın Tarihi:31.12.2018

DOI: $10.26453 /$ otjhs. 434105

Anahtar Kelimeler: Çocuk yoğun bakım ünitesi, hiponatremi, prognoz, mortalite

\section{The clinical importance of hyponatremia in pediatric intensive care unit patients}

Fatih AYGÜN ${ }^{1}$, Seda ARAS ${ }^{2}$, Fatih VAROL ${ }^{1}$, Ahmet İRDEM ${ }^{3}$

\begin{abstract}
Hyponatremia is a common electrolyte deficiency in the setting of the pediatric emergency and intensive care unit. It is already known that hyponatremia is an independent risk factor in the mortality of adult patients. However, the clinical frequency and the importance of hyponatremia are not definitely described in Pediatric Intensive Care Unit (PICU) patients. Herein, we aimed to study the frequency and effect of Hyponatremia to the early prognosis of patients in pediatric intensive care unit. The medical records of patients followed in PICU between October 2016 and March 2018 were evaluated retrospectively. Moderate or severe hyponatremia was determined in 22 of 435 patients included in the study. Twelve $(54.5 \%)$ of patients were male, 10 were $(45.5 \%)$ female. Average age of patients was $3.67 \pm 2.00$ years, ranging between 1.5 months-17 years. The average duration of hospitalization was $14.91 \pm 22.17$ days for patients with hyponatremia. We found a statistically significant correlation between hyponatremia $(\mathrm{Na}<130 \mathrm{mmol} / \mathrm{L})$ and need for mechanical ventilation, use of inotrop drugs, length of hospitalization in PICU, PRISM-III score, blood product need, death, acute kidney injury and cardiac failure. Hyponatremia $(\mathrm{Na}<130 \mathrm{mmol} / \mathrm{L})$ during admission to pediatric intensive care unit should be considered as an important prognostic factor in mortality and morbidity of critically ill children.
\end{abstract}

Article Info

Sorumlu Yazar

Fatih AYGÜN

Keywords: Pediatric intensive care unit, hyponatremia, prognosis, mortality

${ }^{1}$ İstanbul Üniversitesi-Cerrahpaşa, Cerrahpaşa Tıp Fakültesi, Çocuk Yoğun Bakım Bilim Dalı

${ }^{2}$ Sağlık Bilimleri Üniversitesi, Sağlık Uygulama ve Araştırma Merkezi, Okmeydanı Eğitim Araştırma Hastanesi, Çocuk Sağlığı ve Hastalıkları

${ }^{3}$ Sağlık Bilimleri Üniversitesi, Sağlık Uygulama ve Araştırma Merkezi, Okmeydanı Eğitim Araştırma Hastanesi, Çocuk Kardiyolojisi

\section{GíRiș}

Hiponatremi, klinik pratikte en sık karşılaşılan elektrolit bozukluğu olup hastane içi mortalitenin önemli bir habercisidir. ${ }^{1}$ Yoğun bakım ihtiyacı olan yetişkin hastalarda yapılan çalışmalarda hiponatreminin mortalite için bağımsız bir risk faktörü olduğu gösterilmiştir. ${ }^{2,3} \quad$ Hiponatreminin kalp 
yetmezliği, kronik karaciğer hastalı̆̆ sinir sistemi hastalıkları ve pnömoni gibi birçok önemli hastalıkla birlikteliğgi bildirilmiş ve kötü prognoz ile ilişkilendirilmiştir. ${ }^{3}$ Hiponatremi mortalitede artışın yanı sıra hastane yatış süresini de uzatmaktadır. ${ }^{3-5}$ Uzamış yatış süresi ve hiponatremiye ikincil gelişen komplikasyonlar aynı zamanda hastane maliyetlerinde de artışa neden olmaktadır. ${ }^{3,5}$

Çocuk hastalarda yapılan çalışmalarda hiponatreminin alt solunum yolu enfeksiyonları ile ilişkili olduğu bildirilmiş, özellikle bronşiolitli bebeklerde mekanik ventilatör ihtiyacında ve yoğun bakım mortalitesinde artışa nedenolduğu gösterilmiştir. ${ }^{6,7}$ Hiponatremi tek başına da morbidite ve mortaliteyi olumsuz etkilemektedir. Yetişkin hastalarda sodyum $(\mathrm{Na})$ ve hiponatremi ile ilgili birçok çalışma olmasına rağmen çocuk yoğun bakım hastalarında başvuru sırasındaki hiponatremi sıklığı ve prognoza etkisi konusunda az şey bilinmektedir. $\mathrm{Bu}$ çalışmada çocuk yoğun bakım ünitesine (ÇYBÜ) yatırılan hastalarda ilk gün hiponatremi sıklığ 1 ve hiponatreminin erken dönem prognoz ile olan ilişkisinin araştırılması hedeflenmiştir.

\section{MATERYAL ve METOT}

Sağlık Bilimleri Üniversitesi, Okmeydanı Eğitim ve Araştırma Hastanesi Çocuk Yoğun Bakım Ünitesi 12 yatak ile hizmet veren üçüncü düzey bir yoğun bakımdır. Hasta potansiyeli yüksek olan ÇYBÜ’ne Ekim 2016 ile Mart 2018 tarihleri arasında yatırılan tüm hastaların verileri geriye dönük olarak hasta dosyaları ve elektronik kayıt sistemleri üzerinden incelendi. Çalışma için Okmeydanı Eğitim ve Araştırma Hastanesi etik kurulundan 2018-907 say1 numarası ile onam alındı.

Kayıtlarında eksiklik olan ve 24 saatten kısa yatış süresi olan hastalar çalışma dışı bırakıldı. Hafif hiponatremisi $(130<\mathrm{Na}<135 \mathrm{mmol} / \mathrm{L})$ saptanan ve başvuru sırasında kan şekeri $>250 \mathrm{mg} / \mathrm{dl}$ olan hastalar çalışmaya alınmadı. Kan gazında ve izlemdeki laboratuvar değerlendirmelerinde serum $\mathrm{Na}$ düzeyleri karşılaştırılarak uyumsuz olanlar da değerlendirmeye alınmadı.

Çalışmaya alınan hastaların demografik bilgileri ve yatış sonrası ilk laboratuvar değerleri kaydedildi. Serum $\mathrm{Na}$ düzeyleri $\quad(\mathrm{Na}>130$ $\mathrm{mmol} / \mathrm{L}$ ve $\mathrm{Na}<130 \mathrm{mmol} / \mathrm{L}$ ) ile cinsiyet, yaş, mekanik ventilasiyon, non-invaziv mekanik ventilasyon (NIV) ihtiyac1, inotrop ilaç kullanımı, yatışı sırasında akut böbrek hasarı $(\mathrm{ABH})$ gelişmesi, sürekli renal replasman tedavisi (SRRT), yatış süresi, kan ürünü kullanımı, plazma değişimi, kalp yetmezliği ve mortalite ilişkisi değerlendirildi. Ayrıca anlamlı ilişki saptanan prognostik faktörlerin relatif risk oranlarına da bakıldı.

İstatistiksel analizde SPSS programı (20.0 sürümü, IBM Company, SPSS Inc.) kullanıldı. Sayısal veriler ortalama \pm standart sapma, kategorik veriler ise sıklık (n) ve yüzde (\%) ile 
belirtildi. İki grup arasındaki sayısal farklılıkların istatistiksel anlamlılığının değerlendirilmesinde oneway ANOVA kullanıldı. İki değişken arasındaki ilişkinin değerlendirilmesinde Pearson ki kare testi kullanıldı. İstatistiksel anlamlılık $\mathrm{p}$ değerinin 0.05 'in alt1 olarak kabul edildi.

\section{BULGULAR}

Toplamda 459 hastanın verilerine ulaşıldı. Hastaların 24‘ünde kayıtlarında eksiklik, kan şekeri $>250 \mathrm{mg} / \mathrm{dl}$ veya 24 saatten kısa yatış süresi olan hastalar çalışmaya dahil edilmedi. Toplam 435 hasta çalışmaya alındı. Hiponatremi ile yatırılan hastaların 12'si $(\% 54,5)$ erkek, 10’u $(\% 45,5)$ kız idi. Ortalama yaşı $3,67 \pm 2.00$ (1,5 ay ile 17 yaş) yıldı (Tablo 1). Ortalama yatış süresi $14,91 \pm 22,17$ gündü. Mekanik ventilatör desteği $13(\% 59,1)$ ve NIV 9 $(\% 40,9)$ hastaya uyguland 1 . On $(\% 23,7)$ hastada yatışı sırasında $\mathrm{ABH}$ gelişti ve bu hastaların 3’üne $(\% 13,6)$ SRRT yapıldı. On bir $(\% 22,7)$ hastada inotrop ilaç kullanıldı. Pediatrik mortalite risk skorlaması (PRISM-III) $29,62 \pm 17,19$ saptandı. Beş hastaya yoğun bakıma yatışı sonrası kalp yetmezliği tanısı konuldu. Mortalite \%13,6 (n=3) saptandı (Tablo 2).

Serum $\mathrm{Na}<130 \mathrm{mmol} / \mathrm{L}$ ile mekanik ventilatör ihtiyacı, inotrop ilaç kullanımı, ÇYBÜ yatış süresi, PRISM-III skoru, kan ürünü kullanımı, mortalite, $\mathrm{ABH}$ ve kalp yetmezliği arasında istatistiksel olarak anlamlı ilişki saptandı (sırası ile $\mathrm{p}=0,001, \mathrm{p}=0,001, \mathrm{p}=0,00, \mathrm{p}=0,001$, $\mathrm{p}=0,021, \mathrm{p}=0,004, \mathrm{p}=0,024, \mathrm{p}=0,004)$. Serum $\mathrm{Na}<130$ mmol/L olan hastaların mekanik ventilatör, inotrop ilaç kullanımı, ölüm, kan transfüzyonu ihtiyacı, $\mathrm{ABH}$ ve kalp yetmezliği için relatif risk ve güven aralığı Tablo 3' te gösterilmiştir.

\section{TARTIŞMA VE SONUÇ}

Hiponatremi hastanede yatan hastalarda en s1k görülen elektrolit bozukluğu olmasına karşın semptomatik olmadığı sürece sıklıkla önemsenmemektedir. Hafif hiponatremide $(130 \leq \mathrm{Na}<135 \mathrm{mmol} / \mathrm{L}) \quad$ ciddi semptomlar gelişmezken ciddi hiponatremide $(\mathrm{Na}<120 \mathrm{mmol} / \mathrm{L})$ konvülziyon, beyin ödemi, akciğer ödemi ve ölüm gibi çok ciddi komplikasyonlar bildirilmiştir. $^{8}$ ÇYBÜ hastalarında başvuru sırasında hiponatremi sıklığı ile ilgili az çalışma bulunmaktadır. Sachdevve ark. $^{9}$ nın prospektif çalışmasında ÇYBÜ başvurusunda hastaların \%19,3'ünde hiponatremi saptanmıştır. Fakat bu çalışmada bizim çalışmamızdan farklı olarak hafif hiponatremisi olan hastalarda çalışmaya dahil edilmiştir. Hafif hiponatreminin sık görülmesi ve genellikle semptom vermemesi nedeniyle çalışmamıza dahil edilmemiştir ve hiponatremi sıklığımız \%5.0 olarak daha düşük saptanmıştır. Literatüre bakıldığında bizim çalışmamıza benzer şekilde yoğun bakım hastalarında 
$\mathrm{Na}<130 \mathrm{mmol} / \mathrm{L} \quad$ saptanma oran1 \%4-14 arasındadır. $2,5,7$

Hiponatremi etiyolojisinde kronik hastalıklar ve hipervolemiye ikincil gelişimin yanında en sık suçlanan mekanizma stres gibi durumlarda salınımı artan anti-diüretik hormon (ADH) olmuştur. $^{8,10}$ Renin-anjiotension-aldesteron (RAA) sisteminin aktivasyonu da sorumlu tutulan diğer bir mekanizmadır. ${ }^{10}$ Stres durumunda aktive olan ADH ve RAA sistemi hiponatremi sıklığını artırırken, artmış streste hiponatremi derecesinin derinleșeceği düşüncesiyle yaptığımız bu çalışmada hiponatremik grupta mortalite ve morbidite literatür ile uyumlu olarak yüksek saptandı. Çalışmamızda $\mathrm{Na}<130 \mathrm{mml} / \mathrm{L}$ olan grupta mortalite 5,77 kat daha fazlaydı. Funk ve ark. ${ }^{5}$ 151486 yetişkin yoğun bakım hastasını içeren çok merkezli retrospektif çalışmasında hiponatreminin kritik hastalarda hastane mortalitesi için bağımsız bir prognostik faktör olduğu bildirilmiştir. ÇYBÜ hastalarında yapılan çalışmalarda da benzer olarak hiponatreminin mortaliteyi $\operatorname{arttığı~}$ gösterilmiştir. $^{7} \quad$ Çalışmamızda PRISM-III skorunun hiponatremik grupta belirgin yüksek olması serum Na düzeyinin prognoz ile ilişkili olduğunu düşündürmektedir.

Hiponatremik hastalarda yoğun bakım ve mekanik ventilatör ihtiyacında artış ile daha uzun yatış süresi daha önce bildirilmiştir. ${ }^{9.11 .12}$ Bizim çalışmamızda da hiponatremik grupta mekanik ventilatör ihtiyacı belirgin yüksekti.
Yirmi iki hastanın 13'ünde $(\% 59,1)$ mekanik ventilatör ihtiyacı vardı. Ayrıca ÇYBÜ yatış süresi de iki kat daha uzun saptand1. Luu ve ark. $^{7}$ ÇYBÜ hastalarında yaptıkları çalışmada bronşiolitli çocuklarda hiponatreminin yoğun bakım yatış süresini ve mekanik ventilatöre bağlı kalma süresini uzattığı bildirilmiştir. Yoğun bakım yatış süresi uzadıkça maliyetlerinde artacağı beklenen bir durumdur. Fakat çalışmamızda hasta maliyetleri değerlendirilmemiştir.

Hipervolemik hiponatreminin en s1k nedenleri kalp yetmezliği, siroz ve böbrek hasarıdır. ${ }^{13}$ Ayrıca kalp yetmezliği olan hastalarda en s1k görülen elektrolit bozukluğu hiponatremi olup artmış mortalite ve morbidite ile ilişkilidir. ${ }^{14}$ Kalp yetmezliği tanısı ile yatırılan çocuk hastalarda yapılan bir çalışmada serum $\mathrm{Na}<138 \mathrm{mmol} / \mathrm{L}$ olmasının kötü prognoz ile ilişkili olduğu gösterilmiştir. 15 Bizim çalışmamızda da kalp yetmezliği ve inotrop kullanımı ile serum $\mathrm{Na}$ 'u arasında anlamlı ilişki saptandı. Ayrıca hastalarımızda hiponatremi ile $\mathrm{ABH}$ arasında da anlamlı ilişki vardı. Akut hipoalbuminemi, hastanede yatan hastalarda organ disfonksiyonu, malnütrisyon, sistemik inflamasyona bağlı artmış endotel geçirgenliği ve artmış kapiller kaçak gibi nedenlerden dolayı sık görülür. ${ }^{16}$ Hastalarımızın albümin değerlerini incelediğimizde hiponatremik gruptaki 10 hastada hipoalbüminemi saptand1.

Sonuç olarak bu çalışma ile ÇYBÜ hastalarında ilk başvuru $\mathrm{Na}<130 \mathrm{mml} / \mathrm{L}$ olmasının mortalite 
ve morbidite ile ilişkili prognostik bir belirteç olduğu gösterilmiştir. Çalışmamızda bazı eksiklikler ve kısitlamalar bulunmaktadir. Retrospektif ve tek merkezli olması eksik yönleridir. Ülkemizde ÇYBÜ hastalarında başvuru $\mathrm{Na}$ düzeyi ile prognoz arasındaki ilişkiyi karşılaştıran başka bir çalışma olmaması ve hasta topluluğumuzun karma olması çalışmamızı değerli kılmaktadır. Tabii ki bu sonuçlarımızı destekleyecek prospektif ve çok merkezli çalışmalara ihtiyaç olduğunu düşünmekteyiz.

\section{KAYNAKLAR}

1. Hoorn EJ, Lindemans J, Zietse R. Development of severe hyponatraemia in hospitalized patients: treatment-related risk factors and inadequate management. Nephrol Dial Transplant.2006; 21(1):70-76.

2. Bennani SL, Abouqal R, Zeggwagh AA et al. Incidence, causes and prognostic factors of hyponatremia in intensive care. Rev Med Interne.2003;24(4):224-229.

3. Upadhyay A, Jaber BL, Madias NE. Epidemiology of hyponatremia. Semin Nephrol.2009; 29(3):227-238.

4. Chawla A, Sterns RH, Nigwekar SU, Cappuccio JD. Mortality and serum sodium: do patients die from or with hyponatremia? Clin J Am Soc Nephrol. 2011 ;(5):960-965.

5. Funk GC, Lindner G, Druml W et al. Incidence and prognosis of dysnatremias present on ICU admission. Intensive Care Med. 2010; 36(2):304-311.

6. Al Shibli A, Abukhater D, Al Kuwaiti N et al. Hyponatraemia and neurological complications in children admitted with bronchiolitis. Paediatr Int Child Health. 2016;36(3):175-180.

7. Luu R, DeWitt PE, Reiter PD, Dobyns EL, Kaufman J. Hyponatremia in children with bronchiolitis admitted to the pediatric intensive care unit is associated with worse outcomes. J Pediatr. 2013;163(6):1652-1656.

8. Lavagno C, Milani GP, Uestuener $\mathrm{P}$ et al. Hyponatremia in children with acute respiratory infections: A reappraisal. Pediatr Pulmonol. 2017; ;52(7):962-967.

9. Sachdev A, Pandharikar N, Gupta D, Gupta N, Gupta S, Venkatraman ST. Hospital acquired Hyponatremia in Pediatric Intensive Care Unit. Indian J Crit Care Med. 2017;21(9):599-603.

10. Hausman KM, Reif S, Danino D et al. Mechanism of hyponatremia in communityacquired pneumonia: does B-typenatriuretic peptide play a causative role? Pediatr Emerg Care. 2016 May 31:01-06.

11. Waikar SS, Mount DB, Curhan GC. Mortality after hospitalization with mild, moderate, and severe hyponatremia. Am J Med. 2009;122(9):857-865.

12. Dasta J, Waikar SS, Xie L. Patterns of treatment and correction of hyponatremia in 
intensivecare-unit

patients.

CritCare. 2015;30(5):1072-1079.

13. Braun MM, Barstow $\mathrm{CH}$, Pyzocha NJ. Diagnosisand Management of Sodium Disorders: Hyponatremia and Hypernatremia. Am Fam Physician. 2015;91(5):299-307.

14. Price JF, Kantor PF, Shaddy RE et al. Incidence, Severity, and Association With Adverse Outcome of Hyponatremia in Children Hospitalized With Heart Failure. Am J Cardiol. 2016;118(7):1006-1010.
J 15. Patel MS, Berg AM, Vincent RN, Mahle WT. Serum parameters and echocardiographic predictors of death or need for transplant in newborns, children, and young adults with heart failure. Am $\mathbf{J}$ Cardiol. 2010;105(12):1798-801.

16. De Backer D, Creteur J, Preiser JC, Dubois MJ, Vincent JL. Microvascular blood flow is altered in patients with sepsis. Am J Respir Crit Care Med. 2002;166(1):98-104. 
Tablo 1. Ekim 2016 ile Şubat 2018 tarihleri arasında Çocuk Yoğun Bakım yatışı sırasında serum sodyumu $<130 \mathrm{mmol} / \mathrm{L}$ olan hastaların demografik özellikleri

\begin{tabular}{|c|c|c|c|c|c|}
\hline Hasta & Cinsiyet & Yaş & $\begin{array}{c}\mathrm{Na} \\
(\mathrm{mmol} / \mathrm{L})\end{array}$ & Yatış Tanısı & Yatış Süresi \\
\hline 1 & Erkek & 5 ay & 127 & Kronik akciğer, pnömoni & 21 \\
\hline 2 & Erkek & 12 ay & 129 & Down Sendromu, konjenital kalp hst & 23 \\
\hline 3 & $\mathrm{~K} 1 \mathrm{z}$ & 4 ay & 117 & Hidrosefali, şantenfeksiyonu & 31 \\
\hline 4 & Kiz & 6 ay & 127 & Akut Karaciğer yetmezliği & 2 \\
\hline 5 & $\mathrm{~K} 1 \mathrm{z}$ & 4 yaş 8 ay & 118 & Enfektifendokardit & 14 \\
\hline 6 & Kiz & 15 yaş & 119 & Milier Tüberküloz, & 15 \\
\hline 7 & Erkek & 5 yaş & 129 & Epilepsi & 2 \\
\hline 8 & Kiz & 2 yaş & 123 & Asetominofenintoksikasyonu, konvülziyon & 2 \\
\hline 9 & $\mathrm{~K} 1 \mathrm{z}$ & 11 yaş & 129 & Septik şok & 8 \\
\hline 10 & Kiz & 2 yaş 1ay & 129 & Konjenital kalp hastalığı, pnömoni & 11 \\
\hline 11 & Erkek & 2.5 ay & 128 & Bronşiolit & 4 \\
\hline 12 & Erkek & 1.5 ay & 128 & Bronkopnömoni & 11 \\
\hline 13 & $\mathrm{~K} 1 \mathrm{z}$ & 3 ay & 127 & Konjenital kalp hastalığ 1 , bronşiolit & 6 \\
\hline 14 & Erkek & 12 ay & 111 & Mitokondriyal hastalık & 18 \\
\hline 15 & Erkek & 10 ay & 119 & Stroke, epilepsi & 40 \\
\hline 16 & Erkek & 4 ay & 128 & Ani bebek ölümü, preterm doğum & 3 \\
\hline 17 & $\mathrm{~K} 1 \mathrm{z}$ & 15 yaş & 120 & Mide perforasyonu, sepsis & 7 \\
\hline 18 & Erkek & 12 ay & 128 & Febrilkonvülziyon & 2 \\
\hline 19 & Erkek & 13 yaş & 128 & Astım, solunum yetmezliği & 2 \\
\hline 20 & Erkek & 5 yaş & 129 & West sendromu, trakeostomi & 2 \\
\hline 21 & Erkek & 17 yaş & 128 & Ewing sarkom, akciğer metastaz & 10 \\
\hline 22 & $\mathrm{~K}_{1 \mathrm{Z}}$ & 1 yaş & 129 & Meningomyelosel, şantenfeksiyonu & 2 \\
\hline
\end{tabular}

Na: Sodyum 
Tablo 2. Serum sodyumu ile hastaların prognostik faktörlerinin karşılaştırılması.

\begin{tabular}{|c|c|c|c|c|}
\hline & $\begin{array}{l}\text { Tüm hastalar } \\
(n=435)\end{array}$ & $\begin{array}{c}\mathrm{Na}<130 \mathrm{mmol} / \mathrm{L} \\
(\mathrm{n}=22)\end{array}$ & $\begin{array}{c}\mathrm{Na} \geq 130 \mathrm{mmol} / \mathrm{L} \\
(\mathrm{n}=413)\end{array}$ & $\mathbf{p}$ \\
\hline $\mathrm{Na}(\mathrm{mmol} / \mathrm{L})$ & $138.04 \pm 5.42$ & $124.73 \pm 6.04$ & $138.75 \pm 4.37$ & 0.000 \\
\hline \multicolumn{5}{|l|}{ Cinsiyet } \\
\hline Erkek & $236(\% 54.3)$ & $12(\% 54.5)$ & $224(\% 54.2)$ & 0.977 \\
\hline $\mathrm{K} 1 \mathrm{z}$ & $199(\% 45.7)$ & $10(\% 45.5)$ & $189(\% 45.8)$ & \\
\hline Yaş (y1l) & $3.78 \pm 4.72$ & $4.35 \pm 5.73$ & $3,75 \pm 4.66$ & 0.560 \\
\hline Mekanik Ventilatör Kullanımı & $122(\% 28.0)$ & $13(\% 59.1)$ & $109(\% 26.4)$ & $0.001 *$ \\
\hline İnotrop ilaç kullanımı & $96(\% 22.1)$ & $11(\% 50.0)$ & $85(\% 20.6)$ & $0.001 *$ \\
\hline Non-invazif Mekanik Ventilasyon & $197(\% 45.3)$ & $9(\% 40.9)$ & $188(\% 45.5)$ & 0.657 \\
\hline Yoğun Bakım Yatış Süresi & $7.41 \pm 10.39$ & $14.91 \pm 22.17$ & $7.01 \pm 9.25$ & $0.000 *$ \\
\hline PRISM-III skoru & $17.41 \pm 13.29$ & $29.62 \pm 17.19$ & $16.80 \pm 12.81$ & $0.001 *$ \\
\hline Mekanik ventilatör süresi (gün) & $8.99 \pm 14.06$ & $10.38 \pm 12.37$ & $8.81 \pm 14.31$ & 0.706 \\
\hline NIV süresi (gün) & $3.81 \pm 3.83$ & $3.67 \pm 2.00$ & $3.82 \pm 3.89$ & 0.907 \\
\hline Kan ürünü transfüzyonu & $157(\% 36.1)$ & $13(\% 59.1)$ & $144(\% 34.9)$ & $0.021 *$ \\
\hline Plazma değişimi yapılan hastalar & $14(\% 3.2)$ & $2(\% 9.1)$ & $12(\% 2.9)$ & 0.085 \\
\hline Ölüm & $14(\% 3.2)$ & $3(\% 13.6)$ & $11(\% 2.7)$ & $0.004 *$ \\
\hline Akut böbrek hasarı & $109(\% 25.1)$ & $10(\% 45.5)$ & $99(\% 24.0)$ & $0.024 *$ \\
\hline Sürekli renalreplasman tedavisi & $49(\% 11.3)$ & $3(\% 13.6)$ & $46(\% 11.1)$ & 0.721 \\
\hline Kalp Yetmezliği & $31(\% 7.1)$ & $5(\% 22.7)$ & $26(\% 6.3)$ & $0.004 *$ \\
\hline Albumin $\leq 2.5 \mathrm{~g} / \mathrm{dl}$ & $92(\% 21.1)$ & $10(\% 45.5)$ & $82(\% 19.9)$ & $0.005^{*}$ \\
\hline
\end{tabular}

Na: Sodyum, NIV: Non-invazif ventilasyon, PRISM: Pediatrik risk mortalite skoru 
Tablo3.Serum $\mathrm{Na}<130 \mathrm{mmol} / \mathrm{L}$ ile risk faktörlerinin karşılaştırılması.

\begin{tabular}{|l|c|c|}
\hline \multicolumn{1}{|c|}{$\mathbf{N a}<\mathbf{1 3 0} \mathbf{~ m m o l / L ~}$} & RR & $\mathbf{9 5 \%} \mathbf{G A}$ \\
\hline Mekanik Ventilatör Kullanımı & 4.02 & $1.67-9.66$ \\
\hline İnotrop ilaç kullanımı & 3.86 & $1.62-9.20$ \\
\hline Ölüm & 5.77 & $1.49-22.42$ \\
\hline Kan ürünü transfüzyonu ihtiyacı & 2.70 & $1.13-6.46$ \\
\hline Akut böbrek hasarı & 2.64 & $1.11-6.28$ \\
\hline Kalp yetmezliği & 4.38 & $1.49-12.81$ \\
\hline
\end{tabular}

$R R$ : relatif risk oranı; GA: güven aralığ 